\title{
Oliguric glomerulonephritis and parathyroid adenoma
}

\author{
JACQUELINE A. WoOLCOCK* \\ M.A., M.B., M.R.C.P. \\ Senior House Officer
}

\author{
Allen B. Shaw \\ M.B., M.R.C.P. \\ Medical Research Council Research Fellow
}

\section{Summary}

The case is reported of a woman who recovered from acute glomerulonephritis with oliguria of 43 days duration and who subsequently developed hypercalcaemia, treated by parathyroidectomy.

The evidence is presented that the acute nephritis developed in the presence of a primary parathyroid adenoma, providing the natural experiment of hypercalcaemia temporarily depressed by acute renal failure.

\section{Introduction}

The gloomy prognosis of acute oliguric glomerulonephritis (Berlyne \& Baker, 1964) is relieved by occasional reports of recovery following prolonged oliguria (Persoff, 1965). Here we report recovery from acute glomerulonephritis after 43 days of oliguria and discuss the implications of renal biopsy findings in such patients, and their management by dialysis, diet and drugs.

Our patient also had a parathyroid adenoma, later successfully removed. The report illustrates the effect of acute renal failure on the biochemistry of hyperparathyroidism and the difficulty of distinguishing primary from secondary hyperparathyroidism.

\section{Case history}

Two weeks after an attack of scarlet fever in 1946 a 30-year-old housewife was hospitalized for 3 months with haematuria and proteinuria. Thereafter she was well, apart from mild hypertension which was treated during two successful pregnancies by bedrest and induction of labour. In 1960, a few years after her last pregnancy, her blood pressure was $195 / 115 \mathrm{mmHg}$ and she had albuminuria.

At the age of 49 years she became lethargic

*Present address: The Nazareth Hospital, Nazareth, Israel. and unwell 6 weeks after a sore throat but had no urinary symptoms. A few days later, on 1 August 1965, examination revealed a pyrexia of $102^{\circ} \mathrm{F}$, a tachycardia of $120 / \mathrm{min}$, a blood pressure of $220 / 120 \mathrm{mmHg}$, an elevated JVP, cardiomegaly, facial puffiness and albuminuria. The blood urea was $65 \mathrm{mg} / 100 \mathrm{ml}$ on 7 August and $280 \mathrm{mg} / 100 \mathrm{ml}$ on 13 August when she was admitted to hospital. Streptococci were not cultured from the throat but the ASO titre was 800 Todd units. The urine was sterile and the sediment contained red cells, white cells and granular casts. Plain X-ray of the abdomen showed kidneys of normal size.

The blood urea rose to $390 \mathrm{mg} / 100 \mathrm{ml}$ and the average daily urinary output fell below $400 \mathrm{ml}$ ? on 3 September, remaining below this level until 16 October, i.e. 43 days, when a gradual diuresis ensued (Fig. 1). She required four peritoneal dialyses during this time and was treated by a diet for acute renal failure (Berlyne et al., 1967)

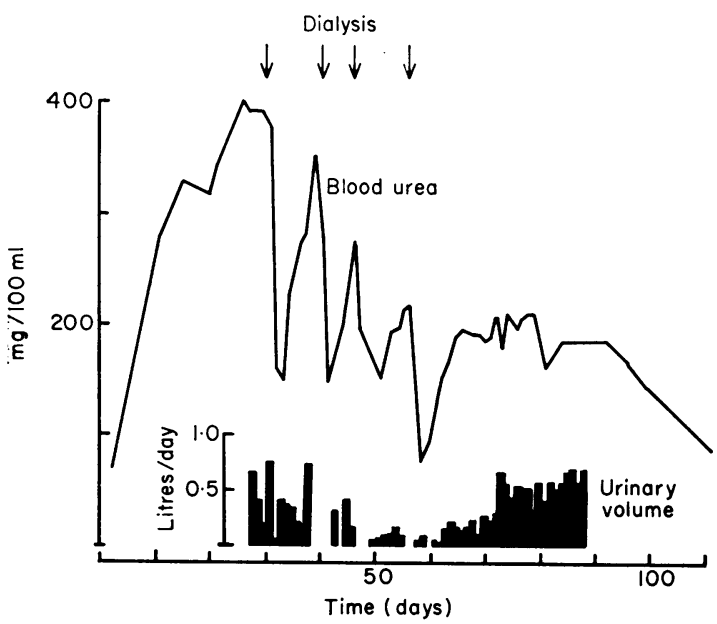

Fig. 1. Blood urea level and urine output. 


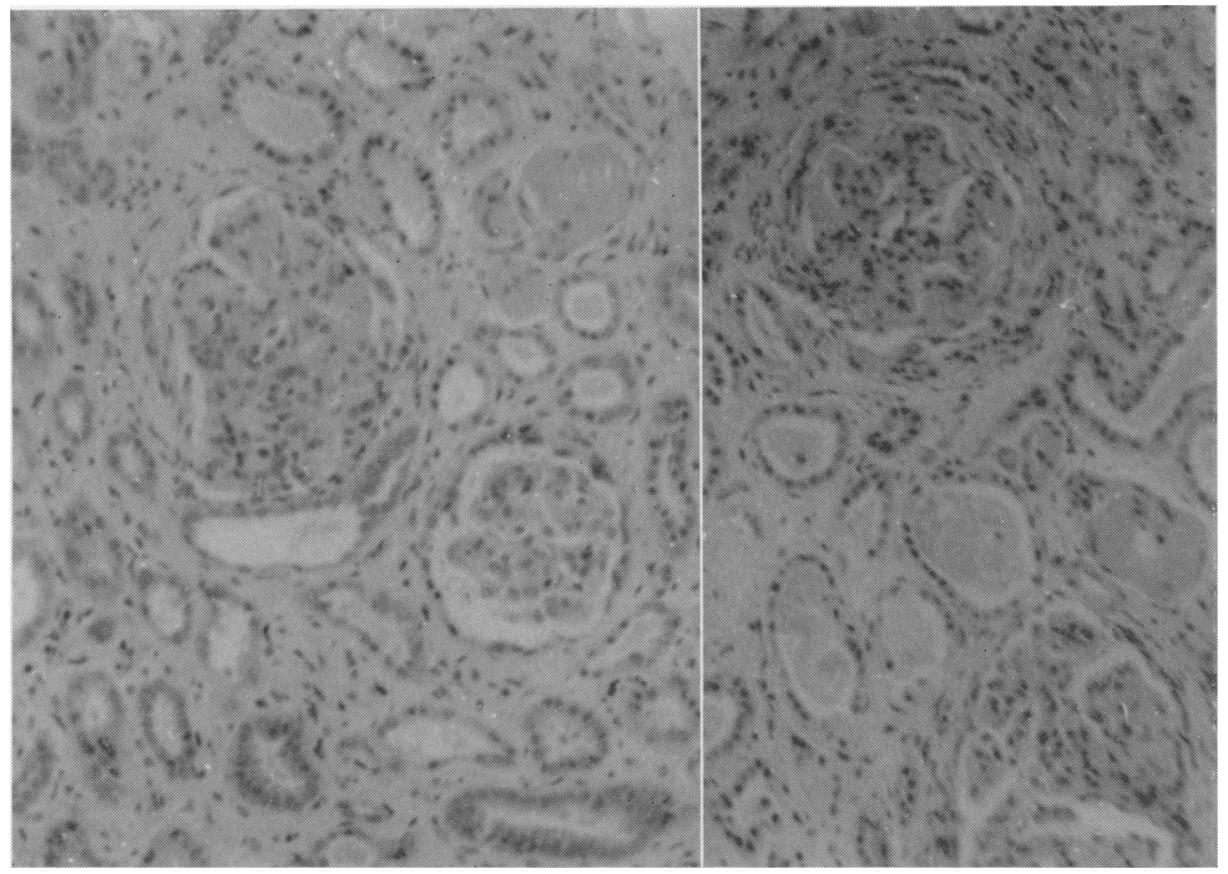

FIG. 2. Renal biopsy specimen stained with haematoxylin and eosin. The four glomeruli shown range from total obliteration of the capsule to mild hypercellularity.

but did not receive corticosteroids or anabolic steroids. Her clinical state remained good throughout and the daily rise of blood urea fell to $9.2 \mathrm{mg} / 100 \mathrm{ml}$. Following the diuresis, her blood urea gradually fell on a low protein diet (Shaw et al., 1965) to a lowest level of $55 \mathrm{mg} / 100 \mathrm{ml}$ and the urea clearance rose to $18.5 \mathrm{ml} / \mathrm{min}$.

Renal biopsy on 24 September showed eleven glomeruli (Fig. 2). Three were largely hyalinized with a completely obliterated capsular space. Five were hypercellular with capsular spaces completely or almost obliterated. Three were hypercellular with minimal or no crescent formation. There was also interstitial calcification and infiltration with lymphocytes. The arterioles showed evidence of benign hypertensive changes.

During the oliguric phase the serum calcium fell to $6.0 \mathrm{mg} / 100 \mathrm{ml}$ with a serum phosphorus of $13.0 \mathrm{mg} / 100 \mathrm{ml}$ and a serum albumin of $2.2 \mathrm{~g} / 100 \mathrm{ml}$. On recovery the serum albumin and phosphorus levels returned to normal and the serum calcium gradually rose to a maximum level of $13.2 \mathrm{mg} / 100 \mathrm{ml}$ (Fig. 3). She developed stiffness of the joints and mild pruritus but no gastro-intestinal symptoms.

Metabolic studies revealed a phosphate clearance of $12.4 \mathrm{ml} / \mathrm{min}$ and a negative calcium and phosphorous balance. Cortisone acetate
$150 \mathrm{mg} /$ day by mouth did not affect the external mineral balance but lowered the serum calcium from 12.7 to $11.5 \mathrm{mg} / 100 \mathrm{ml}$. There was no radiological evidence of hyperparathyroidism and the serum alkaline phosphatase was normal.

On 9 September 1966, three parathyroid glands were removed, two of which showed slight hyperplasia and one was a chief-cell adenoma. Her

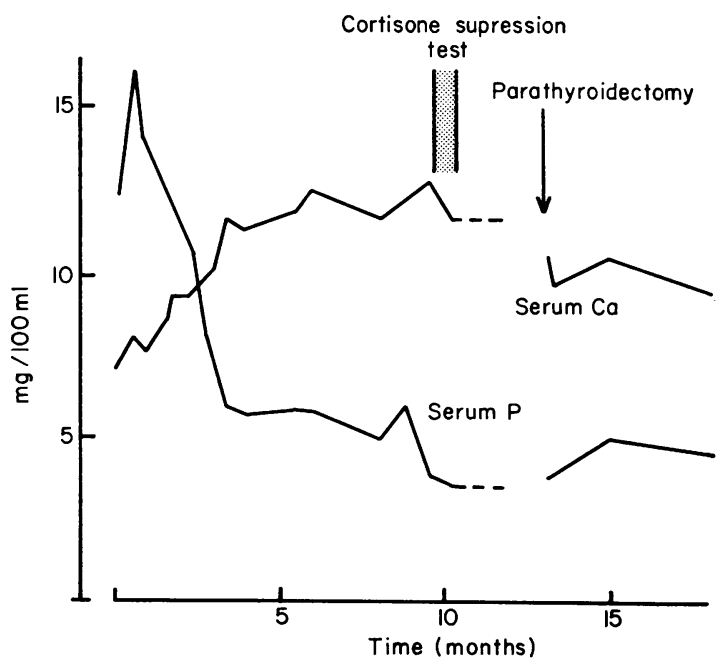

FIG. 3. Serum calcium and phosphorus levels. 
serum calcium fell rapidly to normal (Fig. 3) and the joint stiffness and pruritus disappeared. Her renal function and hypertension were unaffected post-operatively.

\section{Discussion}

This patient had biopsy-proven acute poststreptococcal oliguric glomerulonephritis. This was probably superimposed on pre-existing chronic glomerulonephritis, evidenced by the previous attack of acute glomerulonephritis and subsequent proteinuria and hypertension.

Recovery from acute oliguric glomerulonephritis after an oliguric phase of 43 days, as in our patient, was reported by Alwall et al. (1955). Others have reported recovery after shorter periods of oliguria (Anderson \& Kolff, 1959; Clapp, Holmes \& O’Brien, 1962; Harrison, Loughridge \& Milne, 1964 ; Persoff, 1965).

Recovery is not to be expected where biopsy shows a high percentage of glomeruli with totally obliterated capsular spaces or extensive glomerular fibrosis (Brun et al., 1958 ; Harrison et al., 1964). In all studies recovery has occurred only where some glomeruli have been affected by proliferative changes only, as with this patient. It has been recommended that dialysis should be continued for 6 weeks in oliguric glomerulonephritis (Editorial in Lancet, 1964). However, where the biopsy is favourable it would be wise to maintain the patient through at least 7 weeks in oliguria.

During this time it is as important to maintain nutrition as to control uraemia. This can be achieved by daily haemodialysis combined with free dietary intake as used in traumatic renal failure (Silva et al., 1964). It can be more economically attempted by combining periodic peritoneal dialysis with a diet designed to maintain nutrition and minimize the accumulation of nitrogenous waste products (Berlyne et al., 1967). Corticosteroids were not used in this patient in order to reduce catabolism and the risk of infection. Reports of their ability to induce a diuresis are conflicting (Nakamoto et al., 1965; Berlyne \& Baker, 1964).

The rapid rise in the serum calcium after recovery from oliguria, the nephrocalcinosis, and the histological findings at parathyroidectomy suggest that this patient already had asymptomatic parathyroid hyperfunction when she developed the second attack of acute nephritis. This was masked during the oliguric phase by the hyperphosphataemia and the hypoalbuminaemia, both of which tend to lower the serum calcium level.

The histology and the hypercalcaemia suggest the presence of a parathyroid adenoma with autonomous function. This probably represented primary hyperparathyroidism rather than autonomous function developing in a gland hyperplastic as a result of secondary hyperparathyroidism. Where an autonomous adenoma arises as a result of secondary hyperparathyroidism, the hyperplastic glands are usually very large instead of marginally so (Stanbury \& Lumb, 1967). This situation usually occurs after long-standing severe renal failure, whereas our patient had a blood urea of $65 \mathrm{mg} / 100 \mathrm{ml}$ even after the onset of the second attack of acute nephritis (Stanbury $\&$ Lumb, 1967). Moreover, this patient had hypercalcaemia without radiological evidence of hyperparathyroidism, which is rare in secondary hyperparathyroidism. Depression of the serum calcium level by cortisone in parathyroid hyperfunction is rare, but has been reported previously (Dent, 1962).

\section{Acknowledgments}

We are grateful to Professor D. A. K. Black and Professor S. W. Stanbury (who also performed the calcium balance) for permission to publish this case. We also thank them and Dr G. M. Berlyne for their valuable advice and help.

\section{References}

Alwall, N., Erlanson, P., Wyman, M. \& Tornberg, A. (1955) On the artificial kidney. Acta med. scand. 152, 418 . ANDERSON, A. \& KolfF, W.J. (1959) Artificial kidney in the treatment of uraemia with acute glomerulonephritis. Ann. intern. Med. 51, 476.

Berlyne, G.M. \& BAKer, S.B. DE C. (1964) Acute anuric glomerulonephritis. Quart. J. Med. N.s. 33, 105.

Berlyne, G.M., Bazzard, F.J., Booth, E.M., Janabi, K. \& SHAw, A.B. (1967) The dietary treatment of acute renal failure. Quart. J. Med. N.s. 36, 59.

Brun, C., Gormsen, H., Hilden, T., IVerson, P. \& RAASCHOU, F. (1958) Kidney biopsy in acute glomerulonephritis. Acta med. scand. 160, 155.

Clapp, W.M., Holmes, J. \& O'Brien, D. (1962) Extracorporeal haemodialysis in children. Amer. J. Dis. Child. $104,45$.

DENT, C.E. (1962) Some problems of hyperparathyroidism. Brit. med. J. ii, 1419.

EDITORIAL (1964) Oliguric acute glomerulonephritis. Lancet, i, 1429 .

Harrison, C.V., Loughridge, L. \& Milne, M.D. (1964) Acute oliguric renal failure in acute glomerulonephritis and polyarteritis nodosa. Quart. J. Med. N.s. 33, 39.

Nakamoto, S., Duven, G., KolfF, W.J. \& McCormach, L.J. (1965) Treatment of oliguric glomerulonephritis with dialysis and steroids. Ann. intern. Med. 63, 359.

PersofF, D. (1965) Recovery from prolonged oliguria in acute glomerulonephritis. Lancet, i, 347.

Shaw, A.B., Bazzard, F.J., Booth, E.M., Nilwarangkur, S. \& BERYLYNE, G.M. (1965) The treatment of chronic renal failure by a modified Giovannetti diet. Quart. J. Med. N.s. 34, 237.

Silva, H., Pomeroy, J., Rae, E.A., Rosen, S.M. \& Shaldon, S. (1964) Acute Renal Failure, p. 161. Blackwell Scientific Publications, Oxford.

StanbuRY, S.W. \& LUMB, G.A. (1967) Parathyroid function in chronic renal failure. Quart. J. Med. N.s. 35, 1. 